Canadian Journal of Plant Science Revue canadienne de phytotechnie

\title{
AVG, NAA, boron and magnesium influence preharvest fruit drop and fruit quality of Honeycrisp apples
}

\begin{tabular}{|r|l|}
\hline Journal: & Canadian Journal of Plant Science \\
\hline Manuscript ID & CJPS-2017-0170.R1 \\
\hline Manuscript Type: & Article \\
\hline Complete List of Authors: & $\begin{array}{l}\text { Arseneault, Michelle; University of Guelph, Plant Agriculture, Ontario } \\
\text { Agricultural College } \\
\text { Cline, John; University of Guelph Ontario Agricultural College, Plant } \\
\text { Agriculture }\end{array}$ \\
\hline Keywords: & Abscission, plant bioregulators, ethylene, drop management \\
\hline \multicolumn{2}{|c}{} \\
\hline
\end{tabular}

\section{SCHOLARONE ${ }^{m}$}

Manuscripts 


\title{
AVG, NAA, boron and magnesium influence preharvest fruit drop and fruit quality of \\ Honeycrisp apples
}

\author{
Michelle H. Arseneault, John A. Cline* \\ University of Guelph, Ontario Agricultural College, Department of Plant Agriculture, 1283 \\ Blueline Road, Simcoe, Ontario N3Y 4N5, Canada
}

\begin{abstract}
Preharvest fruit drop (PFD) of apple (Malus domestica Borkh.) can cause significant losses resulting in up to $50 \%$ reduction in yield in some years. In a two-year study, Honeycrisp trees were treated with six foliar treatments including $20 \mathrm{mg} \cdot \mathrm{L}^{-1} 1$-naphthaleneacetic acid (NAA) 2 weeks before anticipated harvest (WBAH), $125 \mathrm{mg} \cdot \mathrm{L}^{-1}$ aminoethoxyvinylglycine hydrochloride (AVG) $4 \mathrm{WBAH}, \mathrm{AVG}$ plus NAA $2 \mathrm{WBAH}$, and repeat sprays of $200 \mathrm{mg} \cdot \mathrm{L}^{-1} \mathrm{~B}$, and $2000 \mathrm{mg} \cdot \mathrm{L}^{-}$

${ }^{1} \mathrm{Mg}$ applied 48 to 93 days after full bloom to evaluate their effect on PFD and fruit quality. Fruit drop associated with broken pedicels and physiological causes was monitored. During a year with $\sim 43 \%$ PFD on untreated control trees, AVG retained up to $\sim 35 \%$ and NAA retained up to $\sim 27 \%$ of the total fruit number, relative to the control trees. The combination of AVG plus NAA had similar PFD compared with AVG alone, while B and Mg were similar to the control. The proportion of PFD associated with broken pedicels was 5\%. Aminoethoxyvinylglycine delayed starch degradation, ethylene evolution, and blush skin colour development of fruit. This study supports the use of AVG 4 WBAH and NAA 2 WBAH to manage Honeycrisp PFD, which may offer economic advantages for growing quality apples. Foliar sprays of $\mathrm{Mg}$ or B failed to reduce PFD.
\end{abstract}


Keywords: Abscission, plant bioregulators, ethylene, drop management.

Abbreviations: AVG, aminoethoxyvinylglycine; DAFB, days after full bloom; WBAH, weeks before anticipated harvest; NAA, 1-naphthaleneacetic acid; PBR, plant bioregulator; PFD, preharvest fruit drop; TCSA, trunk cross-sectional area.

${ }^{*}$ Corresponding author. Tel.: +1 5194267127 x331

E-mail addresses: marsenea@uoguelph.ca (M.H. Arseneault), jcline@uoguelph.ca (J.A. Cline)

Preharvest fruit drop (PFD) of apple (Malus domestica Borkh.) begins approximately four weeks before anticipated harvest (WBAH), and prior to horticultural maturity, with yield loss of up to $50 \%$ in some years (Greene and Schupp 2004). Preharvest fruit drop is a consequence of abscission, a physiological process whereby cell separation in the pedicel sheds the fruit (Addicott 1982). Cultivars differ in their susceptibility to PFD and are categorized as less, intermediate, and more prone to PFD (Irish-Brown et al. 2011). Honeycrisp, a commercially important cultivar, is more prone to PFD compared with other cultivars (Irish-Brown et al. 2011). To avoid PDF, apples cannot be simply picked early, since immature fruit do not have acceptable flavour or colour properties (Baugher and Schupp 2010; Wills et al. 2007).

Plant bioregulators (PBRs) are substances that act on the plant's physiology to alter development; e.g., by delaying PFD or maturity (Arseneault and Cline 2016). A commonly used synthetic auxin, 1-naphthaleneacetic acid (NAA), appears to down-regulate genes involved in cell separation (Greene 2010; Li and Yuan 2008; OMAFRA 2014). In a study on Bisbee Delicious, 
NAA led to delayed PFD, decreased fruit firmness retention, and increased starch index over time (Yuan and Li 2008). Results of using NAA for PFD management can be variable (Robinson et al. 2010; Yildiz et al. 2012). Another PBR, aminoethoxyvinylglycine (AVG) is an ethylene biosynthesis inhibitor that effectively delays PFD (Robinson et al. 2010; Yuan and Li 2008). The use of AVG also maintains firmness retention, slows starch degradation and red blush colour development (Yildiz et al. 2012). Delaying or impeding fruit colour reduces marketability but can be minimized by lowering the rate (concentration) of application or by delaying harvest (Byers and Eno 2002; Greene and Schupp 2004). A combination treatment of AVG plus NAA may be desirable since evidence in McIntosh and Delicious indicates that a combination of AVG plus NAA 1, 2, or 3 WBAH reduces PFD more than either bioregulator applied alone (Robinson et al. 2010; Yuan and Carbaugh 2007). The addition of NAA to AVG might allow colour development, which is sometimes impeded by AVG (Byers 1997; Yuan and Li 2008). Research to delay PFD in specific cultivars has focused on determining effective application timing and rates of PBRs.

Magnesium (Mg) and boron (B) are also of interest because nutrient deficiency is a stress that may lead to PFD (Addicott 1982; Wooldridge 2002). Boron deficiency of pome fruit is associated with fruit abscission (Wooldridge 2002), likely because B deficiency causes cell deterioration and reduces carbohydrate distribution (Addicott 1982). When soil applications of B were applied to McIntosh apple trees, PFD was reduced in trees that were not yet visibly deficient in B (Reuther 1942). Further, Mg deficiency promotes abscission (Southwick 1943) likely because it reduces photosynthesis by limiting production of the chlorophyll molecule, which alters carbohydrate production (Vágó et al. 2007; Yuan and Greene 2000). Foliar sprays of magnesium sulphate reduced PFD of Tydeman's Late Orange apple (Ford 1968) and reduced PFD of apple trees deficient in Mg (Forshey 1959 and 1963). Foliar nutrient sprays of Mg or B 
may be a promising approach to reduce PFD, particularly when nutrient levels are deficient.

Apple fruit that have a short pedicel might be susceptible to fruit drop caused by mechanical damage, including contact with orchard equipment, the force of wind, and the force that growing fruit exert on one another (Poapst et al. 1959; Ward et al. 2001). The proportion of PFD due to mechanical damage versus physiological abscission is unknown (Arseneault and Cline 2016). It may be necessary for investigators to focus on PFD caused by physiological processes rather than mechanical damage by analyzing only fruit with a smooth separation plane on the pedicel (Addicott 1982).

The objectives of this study were to evaluate the effect of NAA, AVG, AVG plus NAA, $\mathrm{B}$, and $\mathrm{Mg}$ on PFD and fruit quality of Honeycrisp apples, and to determine the proportion of fruit that dropped due to broken pedicels caused by wind or fruit being pushed off by each other.

\section{MATERIALS AND METHODS}

\section{Experimental Design}

A two-year investigation was conducted to evaluate the effect of two PBRs and foliar nutrients on PFD. In 2014, six-year-old Honeycrisp/M.26 trees trained to a slender spindle orchard system were used at 'Site A,' the University of Guelph Research Station in Simcoe, Ontario, Canada. In 2015, fruit set was poor because of frost damage; therefore, another commercial orchard in Windham Centre, ON, ('Site B') was chosen (4255'54.7"N $80^{\circ} 23^{\prime} 43.5^{\prime \prime}$ ). Eleven-year-old Honeycrisp/M.9 trees were trained to a vertical axis orchard system. The use of dwarf and semi-dwarf rootstock in 2014 and 2015, respectively, were not a concern to the variables being studied, as dwarfing rootstocks have a similar influence on PFD and fruit maturity (Miller and Racsko 2011; Southwick 1938). Trees used during both years were 
pruned and trained in a similar fashion at approximately $3.0 \mathrm{~m}$ tall, spaced $1.2 \mathrm{~m}$ in-row and 4.0 $\mathrm{m}$ between-rows $\left(2,083\right.$ trees $\left.\mathrm{ha}^{-1}\right)$. Treatment trees were selected based on a visual assessment of uniform canopies and fruit density. The soil was a well-drained, coarse sand to sandy loam. Each treatment plot consisted of two trees: one tree was used for monitoring fruit drop and the other was used to sample fruit for quality and yield.

Trees were managed according to standard Ontario orchard practices for Honeycrisp, including foliar sprays of calcium chloride to decrease bitter pit and improve storage potential (OMAFRA 2014). Fruit were thinned by singling clusters and spacing fruit $\sim 10 \mathrm{~cm}$ apart; this was done to reduce the likelihood that clusters of more than one fruit would not lead to fruit being 'pushed' off the spur, causing fruit drop.

\section{Chemical Fruit Drop Management Treatments and Cumulative Fruit Drop Proportion}

The following six foliar treatments were applied in a randomized complete block design with six replications: 1) untreated control; 2) $125 \mathrm{mg} \cdot \mathrm{L}^{-1}$ AVG (ReTain ${ }^{\circledR}$ ABG 3168 'aminoethoxyvinylglycine hydrochloride'; Valent BioSciences, Libertyville, IL) applied 4 WBAH; 3) $20 \mathrm{mg} \cdot \mathrm{L}^{-1} \mathrm{NAA}\left(\right.$ Fruitone ${ }^{\circledR} \mathrm{L}$; AMVAC Chemical Corp., Los Angeles, CA) applied 2 WBAH; 4) $125 \mathrm{mg} \cdot \mathrm{L}^{-1}$ AVG tank mixed with $20 \mathrm{mg} \cdot \mathrm{L}^{-1} \mathrm{NAA}$ applied $2 \mathrm{WBAH}$; 5) $200 \mathrm{mg} \cdot \mathrm{L}^{-1} \mathrm{~B}$ (Solubor ${ }^{\circledR} 20.5 \%$ B; 20 Mule Team, Greenwood Village, Colorado); and 6) $2000 \mathrm{mg} \cdot \mathrm{L}^{-1} \mathrm{Mg}$ (Epsom salt 10\% Mg; Pestell Minerals \& Ingredients, New Hamburg, Ontario). In 2014, B was applied as three repeat foliar sprays 48, 61, 78 days after full bloom (DAFB) and Mg in four repeat sprays at 48, 61, 78, and 93 DAFB. In 2015, both B and $\mathrm{Mg}$ were applied in two repeat sprays, at 53 and 67 DAFB. The number of repeat sprays was reduced in 2015 because the commercial orchard received a broadcast ground application of calcium nitrate $224 \mathrm{~kg} \cdot \mathrm{ha}^{-1}$ 
applied pre-bloom within the herbicide strip and two foliar applications of "Magical Max" 2.5 $\mathrm{kg} \cdot \mathrm{ha}^{-1}(5.5 \% \mathrm{Ca}, 2.0 \% \mathrm{Mg}, 0.5 \% \mathrm{~B})$ (NutriAg, Toronto, ON) during the growing season. Anticipated harvest dates used to base PBR spray timing were 7 Sept 2014 (108 DAFB) and 9 Sept 2015 (117 DAFB). At least one guard tree separated adjacent two-tree plots to prevent treatment cross-contamination due to spray drift (Unrath et al. 2009). Treatments were applied using a commercial airblast sprayer (GB Irrorazione Diserbo, Model Laser P7, Italy) at $1379 \mathrm{kPa}$, $\sim 1000 \mathrm{~L} \mathrm{ha}^{-1}$. All treatments included $500 \mathrm{~mL} \cdot \mathrm{L}^{-1}$ Regulaid $\circledast$ surfactant (KALO, Inc.; Overland Park, KS) and 0.5-1.0 mL of Halt ${ }^{\mathrm{TM}}$ (Dow AgroSciences; Calgary, Alberta), a neutral antifoaming agent. Treatments were applied in the morning or early afternoon when no rain was forecasted within 24 hours. In 2014 there was an exception when it rained $\sim 8 \mathrm{~mm}$ within 24 hours of applying Mg and B at 48 DAFB. In 2015, 22 mm of rain fell within 24 hours of applying $\mathrm{Mg}$ and B at $53 \mathrm{DAFB}$.

When PFD began in late August, dropped fruit from the 'monitor' tree were counted three days per week and discarded after each day. Fruit were categorized according to the cause of fruit drop; a jagged tear-like appearance of the pedicel indicated a broken pedicel, and smooth appearance indicated separation at the abscission zone (Fig. 1).

\section{Leaf Nutrients}

The effect of foliar nutrient treatments on leaf $\mathrm{B}$ and $\mathrm{Mg}$ nutrient concentration was determined by leaf tissue analyses from the control, B, and $\mathrm{Mg}$ treatments only. In mid-August at 96 and 84 DAFB in 2014 and 2015, respectively, 25 healthy leaves were sampled $1.5 \mathrm{~m}$ from the ground around each tree in each experimental plot (OMAFRA 2014). Only extension shoot leaves from the middle of the current season's growth were included in the sample (OMAFRA 2014). Leaf samples were rinsed three times with distilled water to remove any spray residue, 
then placed in a paper bag and dried in a forced-air oven at $60^{\circ} \mathrm{C}$ for one week. Samples were ground for analysis in a pulverizing mill using a 2-mm mesh (Thomas Scientific, Swedesboro, NJ) and analyzed in a commercial laboratory, following the Official Methods of Analysis of the Association of Analytical Communities (AOAC 2012).

\section{Fruit Yield and Quality}

All Honeycrisp fruit from the sample tree were harvested to determine yield $\left(\mathrm{kg}_{\text {fruit }} \cdot \mathrm{tree}^{-1}\right)$. Total yield included dropped fruit, while all measurements of marketable yield excluded dropped fruit. Trunk cross-sectional area (TCSA) was calculated based on trunk diameter measurements taken in the spring, $30 \mathrm{~cm}$ above the graft union, using a flexible measuring tape. Crop load was calculated by dividing the total number of fruit per tree by TCSA (Marini 2004).

Fruit quality was evaluated on 10 representative, undamaged fruit selected from the sample tree; fruit were taken from all sides as well as the interior and exterior areas. These fruit were used for fruit quality analyses to indicate fruit marketability, as follows. The rate of ethylene production was determined on the headspace of an enclosed pail that contained 10 fruit, which was analyzed using gas chromatography with an active alumina column and a flame ionization detector running at $70^{\circ} \mathrm{C}$ (Model $8610 \mathrm{C}$; SRI Instruments, Torrance, CA). Fruit blush and ground colour were measured using a Minolta colorimeter (Model CR-400; Konica-Minolta, Tokyo, Japan) to determine lightness $\left(\mathrm{L}^{*}\right)$, chroma $\left(\mathrm{C}^{*}\right)$, and hue $\left(\mathrm{H}^{0}\right)$. Fruit firmness was measured on opposite sides of the fruit, on peeled flesh, using an electronic penetrometer with an $11.1 \mathrm{~mm}$ diameter blunt probe, travelling at $10 \mathrm{~mm} \mathrm{~s}^{-1}$ to a depth of $8.9 \mathrm{~mm}$ (Fruit Texture Analyzer GS14; Western Cape, South Africa). Starch-iodine index value was determined based on the intensity and pattern of staining when a laterally-sliced fruit was dipped in iodine solution 
(Blanpied and Silsby 1992). Soluble solid concentration was analyzed using a temperaturecompensating digital refractometer (Model Palette PR-32x; Atago, Tokyo), while titratable acidity was measured by diluting $5.0 \mathrm{~mL}$ of juice with $45.0 \mathrm{~mL}$ of water and then titrating with $\mathrm{NaOH}$ to a $\mathrm{pH}$ endpoint of 8.2, using an automatic titrator (Model G20; Mettler- Toledo, Columbus, $\mathrm{OH})$.

\section{Statistical Analysis}

Treatments were arranged in a randomized complete block design; each experimental unit consisted of a single tree, replicated six times at both locations. The error variance for yield and fruit quality parameters was analyzed using a 'Proc Mixed,' mixed-model ANOVA (SAS version 9.3; SAS Institute, Cary, NC), with treatments entered as fixed effects and blocks as random effects. The initial difference in tree size between experimental units was adjusted by including TCSA as a covariate. Tukey’s multiple means comparison test was used, and significance of treatment effects was determined using a Type I error rate of $\mathrm{P}<0.05$. Graphs were generated using SigmaPlot v.11.0 (Systat Software Inc., San Jose, CA).

\section{RESULTS}

\section{Cumulative PFD Ratio and Fruit Quality, Simcoe Research Station (Site A)}

In 2014, PFD from untreated control trees was 4\% by 24 Sept when harvest began, and had increased to $11 \%$ on 2 Oct, when the commercial harvest period ended (Fig. 2A). Cumulative fruit drop on untreated trees increased rapidly from 24 Sept to 6 Oct; the trend was flat thereafter. Trees treated with Mg had fruit drop similar to the untreated control. Trees treated with B had up to $7 \%$ higher fruit drop compared with the untreated control. The AVG, NAA, and AVG plus NAA treatments all reduced PFD by $4 \%$ and to a similar level. Trees treated with NAA, AVG, or 
AVG plus NAA did not display a period of rapid fruit drop during the monitoring period. Fruit drop due to broken pedicels, likely removed by wind or fruits physically 'pushing' each other, contributed an additional $\sim 5 \%$ fruit drop on the untreated control by 2 Oct (Fig. 3A).

Untreated control trees had leaf B concentrations of $22 \mu \mathrm{g} \cdot \mathrm{g}^{-1}$ (dry weight), considered low according to local sufficiency ranges for apples; i.e., 20-60 $\mu \mathrm{g} \cdot \mathrm{g}^{-1}$ (OMAFRA 2014) (Table 1). Application of $200 \mathrm{mg} \cdot \mathrm{L}^{-1} \mathrm{~B}$ as three repeat foliar sprays significantly increased leaf $\mathrm{B}$ concentration by $\sim 54.2 \mu \mathrm{g} \cdot \mathrm{g}^{-1}$ compared to the untreated control $(\mathrm{P}<0.0001)$, resulting in a level that is excessive in the local nutrient concentration sufficiency range for apples (OMAFRA 2014). Untreated control trees had low leaf $\mathrm{Mg}$ concentration at $0.22 \%$ (dry weight) according to the sufficiency range of $\mathrm{Mg}$ for apples, which is $0.25-0.40 \%$ (OMAFRA 2014). Application of $2000 \mathrm{mg} \cdot \mathrm{L}^{-1} \mathrm{Mg}$ as four repeat sprays significantly increased leaf $\mathrm{Mg}$ concentration by $\sim 0.19 \%$ compared with the untreated control $(\mathrm{P}<0.0001)$. Magnesium treatment resulted in leaves with Mg levels considered slightly excessive at $0.41 \%$.

At harvest, treated trees had similar marketable yield, marketable fruit number, marketable fruit weight, and marketable crop load compared with the control ( $\mathrm{P}>0.05$; Table 2). Fruit firmness was similar between treatments and untreated controls, with the exception that fruit firmness in the NAA treatment was significantly lower $(\sim 4 \mathrm{~N})$ compared with treatments of AVG and AVG plus NAA $(\mathrm{P}<0.0001)$ (Table 3). The starch index for fruit from the AVG treatment was significantly lower compared with the AVG plus NAA treatment by 1.6 $(\mathrm{P}<0.0001)$. Starch indices for fruit from the treatments AVG, and AVG plus NAA were significantly lower compared with the untreated control by 2.5 and 0.9 , respectively $(\mathrm{P}<0.0001)$. The rate of ethylene evolution of fruit at harvest was significantly lower for the AVG treatment, at $0.2 \mathrm{~nL}$ ethylene $\cdot \mathrm{g}$ fruit ${ }^{-1} \cdot \mathrm{hr}^{-1}$; AVG plus NAA was below the detectable limit, compared with 
the untreated control that produced $12.2 \mathrm{~nL}$ ethylene $\cdot g$ fruit ${ }^{-1} \cdot \mathrm{hr}^{-1}$. Titratable acidity $(\mathrm{P}=0.6278)$ and soluble solids $(\mathrm{P}=0.0026)$ were similar between treatments and the control (Table 3$)$.

Fruit skin blush colour when treated with AVG and AVG plus NAA resulted in skin blush colour that was lighter, faded, and less similar to red, respectively (Table 4). Treatment with AVG and AVG plus NAA resulted in skin ground colour that was more vivid and more similar to green.

\section{Cumulative PFD Ratio and Fruit Quality, Windham Centre (Site B)}

In 2015, cumulative PFD from the untreated control trees was $27 \%$ by 25 Sept at the beginning of the commercial harvest period, and increased to $43 \%$ on 7 Oct, when the harvest period ended (Fig. 2B). Fruit drop on untreated control trees increased rapidly from 16-28 Sept and increased at a constant rate thereafter. The $\mathrm{Mg}$ treatment reduced fruit drop by up to $6 \%$ while the B treatment increased fruit drop by up to $8 \%$, compared with the untreated control at the end of the harvest period. Fruit drop on trees treated with NAA was 20-27\% lower than the untreated control during the harvest period. Trees treated with AVG had 24 and $35 \%$ lower fruit drop at the beginning and end of harvest, respectively. The combination of AVG plus NAA had similar PFD levels to AVG alone. Trees treated with NAA, AVG, or AVG plus NAA did not display a rapid increase in fruit drop. Fruit drop by broken pedicels resulted in $\sim 2 \%$ fruit drop on the untreated control by 7 Oct (Fig. 3B).

Untreated control trees had a leaf B concentration of $34 \mu \mathrm{g} \cdot \mathrm{g}^{-1}$, which was within the sufficiency range (OMAFRA 2014) (Table 1). Treatment with $200 \mathrm{mg} \cdot \mathrm{L}^{-1} \mathrm{~B}$ applied as two repeat sprays significantly increased leaf B concentration by $\sim 5.3 \mu \mathrm{g} \cdot \mathrm{g}^{-1}$, compared with the untreated control $(\mathrm{P}=0.0123)$. Untreated control trees were deficient in $\mathrm{Mg}$, at $0.19 \%$ (OMAFRA 
2014). Application of $2000 \mathrm{mg} \cdot \mathrm{L}^{-1} \mathrm{Mg}$ as two repeat sprays significantly increased leaf $\mathrm{Mg}$ concentration by $\sim 0.08 \%$ compared to the untreated control $(\mathrm{P}=0.0015)$. Mg treatment increased leaf $\mathrm{Mg}$ concentration from deficient to a low sufficiency level of $0.27 \%$.

At harvest, treatments with respect to the control had similar total yield, marketable fruit weight, marketable fruit number, and marketable crop load (Table 5). Marketable yields for the AVG and NAA treatments were significantly higher than the untreated control by 7.6 and 8.4 $\mathrm{kg} \cdot \operatorname{tree}^{-1}(44 \%$ and $48 \%)$, respectively $(\mathrm{P}=0.0003)$.

The starch indices were significantly lower for AVG and AVG plus NAA treatments, by $\sim 2.7$ and 1.6, respectively, compared with the untreated control $(\mathrm{P}<0.0001)($ Table 6$)$. Titratable acidity was significantly higher for the AVG treatment compared with NAA ( $\mathrm{P}=0.0144)$; however, there was no difference between the control and any treatment (Table 6). The rate of ethylene evolution of fruit from trees treated with AVG was $0.2 \mathrm{~nL}$ ethylene $\cdot \mathrm{g}$ fruit $^{-1} \cdot \mathrm{hr}^{-1}$; AVG plus NAA was below the detectable limit. These rates of ethylene evolution were both significantly lower compared with the untreated control, which produced $14.3 \mathrm{~nL}$ ethylene.g fruit ${ }^{-}$ ${ }^{1} \cdot \mathrm{hr}^{-1}$ (Table 6) $(\mathrm{P}<0.0001)$. There were no significant treatment effects on fruit firmness $(\mathrm{P}=0.1585)$ or soluble solids $(\mathrm{P}=0.4590)$.

Fruit skin blush colour was significantly affected by AVG, as indicated by the AVG and AVG plus NAA treatments, which were lighter and less similar to red compared with untreated fruit (Table 7). Fruit ground colour of AVG and Mg treatments was lighter compared with the untreated control.

\section{DISCUSSION}

\section{Cumulative Fruit Drop}


The propensity for Honeycrisp PFD can be managed to some extent by foliar PBR sprays applied prior to harvest (Hoying and Robinson 2010). In the current study, application of AVG 4 WBAH delayed fruit drop of Honeycrisp, which is consistent with studies of McIntosh (Robinson et al. 2010), Golden Supreme (Yuan and Carbaugh 2007), and Bisbee Delicious (Yuan and Li 2008). Previous research indicates that AVG delays PFD by reducing ethylene synthesis in fruit (Boller et al. 1979; Yuan and Li 2008).

Application of NAA 2 WBAH reduced fruit drop by up to $\sim 27 \%$, which is thought to be the result of NAA down-regulating genes involved in cell separation (Li and Yuan 2008). Results of the current study are consistent with previous studies using NAA on Red Chief Red Delicious (Marini et al. 1993), Golden Supreme, and Golden Delicious (Yuan and Carbaugh 2007). However, previous research on McIntosh indicates that NAA is not always effective at delaying PFD (Schupp and Greene 2004). In 2015, when PFD was 43\%, AVG was superior to NAA at delaying PFD, which is consistent with the study by Yuan and Carbaugh (2007). The current study indicates that single applications of AVG 4 WBAH and NAA 2 WBAH are effective treatments for delaying PFD in Honeycrisp.

Yuan and $\mathrm{Li}$ (2008) concluded that $125 \mathrm{mg} \cdot \mathrm{L}^{-1} \mathrm{AVG}$ and $20 \mathrm{mg} \cdot \mathrm{L}^{-1} \mathrm{NAA}$ applied alone delay PFD and their effect is additive when combined. However, those PFD measurements were made beyond the commercial harvest window, when drop control is no longer useful. The current study indicates that combining AVG with NAA in the same concentrations as Yuan and Li (2008) showed no benefit of adding NAA in reducing fruit drop of Honeycrisp apples. Future research on Honeycrisp is warranted to investigate whether the combination of AVG plus NAA is effective at lower rates of AVG compared with the full rate of $125 \mathrm{mg} \cdot \mathrm{L}^{-1} \mathrm{AVG}$ alone, as this could reduce the cost of application and negative effects of AVG on maturity (Yuan and 
Carbaugh 2007; Yuan and Li 2008).

Mg spray treatments did not reduce fruit drop in 2014, while in 2015 fruit drop was reduced by 6\%. Ford (1968) demonstrated reduced PFD of Tydeman's Late Orange apples when they were treated with foliar sprays of magnesium sulphate (i.e., Epsom salts).

In both years of this study, B application resulted in up to $8 \%$ higher fruit drop compared with the untreated control. Previous studies have demonstrated that B application hastened fruit maturity at harvest (Wójcik et al. 1999), and that more mature fruit are more likely to drop compared with less mature fruit (Greene et al. 2014; Poapst et al. 1959). Current study results suggest that preventative foliar sprays of $\mathrm{Mg}$ and $\mathrm{B}$ were relatively ineffective for the management of PFD, and that B may have inadvertently increased fruit drop.

The percentage of fruit drop varied between the two study years. Preharvest fruit drop of Honeycrisp is reportedly as severe as McIntosh, the latter of which is well known to drop early (Rosenberger et al. 2001). Previous research on McIntosh showed that fruit drop varied by year, ranging from $27-51 \%$ ( $27 \mathrm{Sept}$ ) in a two-year period (Schupp and Greene 2004). Factors that vary between years and may affect fruit drop include wind speed, moisture stress, sunlight levels, air temperature, and nutrient availability. These factors may promote fruit abscission if they cause stress and deprive the plant of energy (Roberts et al. 2002). In addition, previous research on McIntosh showed that fruit drop varied by location in the same year, ranging from $30-70 \%$ from Geneva to Hudson, New York ( $\sim 30$ Sept)(Robinson et al. 2010). Factors that differed between both sites (e.g., tree age, tree health, soil type, average air temperature) may explain the variation in PFD observed herein.

There are reports that external forces (e.g., wind, orchard equipment touching fruit, and closely-growing fruit exerting pressure on one another) cause fruit drop, and yearly variations in 
the intensity of these factors may contribute to variation of PFD (Poapst et al. 1959; Ward et al. 2001). In the current study, the proportion of broken pedicels was not especially large or variable. The study by Ward et al. (2001) excluded apple fruit without an attached pedicel when monitoring fruit drop; however, the current study is the first to quantify fruit drop associated with broken pedicels. Fruit drop by broken pedicels caused predictable fruit drop each year.

\section{Leaf Nutrients}

In 2014, leaf B and $\mathrm{Mg}$ concentrations in the control treatment were low, and foliar treatments of $\mathrm{B}$ and $\mathrm{Mg}$ increased the corresponding leaf nutrients to excessive levels. The increase in leaf B concentration of $54.2 \mu \mathrm{g} \cdot \mathrm{g}^{-1}$ and $\mathrm{Mg}$ of $\sim 0.19 \%$ in the current study were relatively high in relation to previous research, and several factors may explain this increase (Wojcik et al. 2008; Wojcik and Wojcik 2006; Wooldridge 2002). A surfactant was applied, similar to Ullah et al. (2012), which was expected to increase uptake. Leaves were sampled within two weeks after the final spray, which may not have allowed time for B to translocate from leaves to other plant tissues (Hanson 1991).

The limited increase in leaf B in 2015 did not appear to be due to differences in translocation between stage of development, as nutrients were measured at similar times during the growing season each year. Two foliar sprays were applied in 2015, compared with three in 2014; this likely led to a lower nutrient uptake in 2015. Nutrient absorption may have been lower in 2015 due to $22 \mathrm{~mm}$ of rainfall the day after the first foliar spray, which may have reduced the treatment effect.

\section{Fruit Yield and Quality at Harvest}


The higher marketable yields of AVG and NAA treatments compared with the control are consistent with other studies showing a delay of PFD associated with AVG (Greene 2006; Yuan and Li 2008) and NAA (Yuan and Carbaugh 2007). Treatments during the current study were harvested on the same date, explaining why no differences in fruit weight were observed. Other studies have indicated that fruit weight can increase when fruit remain on the tree during a delayed harvest (Byers and Eno 2002).

Previous research reported that AVG did not affect fruit firmness of McIntosh (Robinson et al. 2006) or Delicious (Byers 1997; Greene 2002) at the usual harvest period, which is consistent with the current study. In contrast, studies have also shown that AVG delayed the loss of fruit firmness on Red Chief (Yildiz et al. 2012), and McIntosh (Greene 2005). The results of the current study using Honeycrisp align with studies reporting that NAA was not associated with loss of firmness at harvest for Red Chief (Yildiz et al. 2012) or Starkrimson Delicious (Byers 1997). However, NAA was associated with a loss of fruit firmness in Golden Supreme, Golden Delicious (Yuan and Carbaugh 2007), Bisbee Delicious (Yuan and Li 2008), and Macspur McIntosh (Schupp and Greene 2004). Several factors may explain these inconsistencies of fruit firmness between years and studies, including fruit size, number and size of cells, maturity at harvest, and enzyme activity (Link 2000). Honeycrisp flesh is not prone to rapid loss of firmness according to previous research, likely due to low enzyme activity (Harb et al. 2012). The effect of an extended harvest on fruit firmness in Honeycrisp is an area for further research.

In both years of this study, AVG treatments had lower starch index values and lower rates of ethylene evolution than the untreated control, and hence delayed fruit maturity, consistent with other studies (Byers et al. 2005; Greene 2005; Yuan and Carbaugh 2007; Yuan and Li 2008). These results are consistent with those by Greene (2006), which found that $90 \mathrm{mg} \cdot \mathrm{L}^{-1} \mathrm{AVG}$ 
markedly delayed ripening of the low-ethylene producing Gala, and suggested a similar influence on Honeycrisp, although data were not shown. Other studies suggest that NAA hastens starch degradation (Schupp and Greene 2004; Yuan and Li 2008). The current study could not discern whether NAA hastened starch degradation compared with the control because fruit from treatments were harvested at a high starch index, when most starch hydrolysis to sugar had occurred. Regarding ethylene evolution, previous studies indicated that AVG delayed the rate of ethylene biosynthesis in apple fruit (Robinson et al. 2010; Schupp and Greene 2004). Similarly, results of this investigation demonstrated that the rate of ethylene evolution of fruit was low for all treatments containing AVG.

This two-year study indicated that in Honeycrisp, the use of AVG or NAA had no clear relationship with soluble solids or titratable acidity. Other studies report conflicting results on the effect of drop management compounds on soluble solids and titratable acidity, but effects appear to be minor (Greene 2002; Yildiz et al. 2012).

Consumers prefer bicoloured fruit cultivars such as Gala or Honeycrisp, which have a red blush colour of high surface coverage and intensity (Iglesias et al. 2008; Rosenberger et al. 2001). Red colour development is often slowed or impaired by AVG, likely because of a delay in maturity rather than a direct chemical effect on colour (Dal Cin et al. 2008; Greene 2006). In 2014 of the current study, AVG and AVG plus NAA treatments resulted in fruit skin with a greener ground colour, which is indicative of delayed maturity. This was also reported by Dal Cin et al. (2008). When AVG is used, and depending on concentration, harvest may need to be delayed to allow acceptable colour development for horticultural maturity (Schupp and Greene 2004; Yildiz et al. 2012). 


\section{CONCLUSIONS}

Aminoethoxyvinylglycine and 1-naphthaleneacetic acid are effective tools to delay fruit drop in Honeycrisp. However, combining NAA with AVG did not delay PFD any more than using AVG alone. Foliar sprays of B and Mg did not adequately reduce fruit drop. The proportion of fruit drop by pedicel breakage was $\sim 5 \%$, a value that was previously only speculated, compared with $\sim 43 \%$ by physiological causes. AVG delayed fruit maturity, as indicated by lower starch index values, lower rates of ethylene evolution, and reduced skin blush red colour. Plant bioregulators may reduce production losses on the popular cultivar Honeycrisp.

\section{ACKNOWLEDGEMENTS}

The authors appreciate the generous financial support for this project: The University of Guelph - Ontario Ministry of Agriculture and Food Research Program, Queen Elizabeth II Graduate Scholarship in Science \& Technology, the Walter and Laura Scott Tree-Fruit Scholarship and ReTain ${ }^{\circledR}$ supplied by Valent BioSciences. The technical support of Ms. A. Gunter in the field and the laboratory is gratefully acknowledged. 
Addicott, F. 1982. Abscission. Pages 1-369. University of California Press, 1 eds. Berkeley, Los Angeles, London.

AOAC, 2012. Official methods of analysis of AOAC international. AOAC International, 19 eds. Gaithersburg, Maryland, USA.

Arseneault, M. H. and Cline, J. A. 2016. A review of apple preharvest fruit drop and practices for horticultural management. Sci. Hortic. 211: 40-52. doi:10.1016/j.scienta.2016.08.002

Baugher, T. A. and Schupp, J. R. 2010. Relationship between 'Honeycrisp' crop load and sensory panel evaluations of the fruit. J. Am. Pomol. Soc. 64: 226-233.

Blanpied, G. D. and Silsby, K. J. 1992. Predicting harvest date window for apples in: A Cornell Cooperative Extension Publication. Info. Bull. 221. Ithaca, NY.

Boller, T., Herner, R. C. and Kende, H. 1979. Assay for and enzymatic formation of an ethylene precursor, 1-aminocyclopropane-1-carboxylic acid. Planta. 145: 293-303.

Byers, R. E. 1997. Effects of aminoethoxyvinylglycine (AVG) on preharvest fruit drop, and maturity of 'Delicious' apples. J. Tree Fruit Prod. 144: 121-124.

Byers, R. E. and Eno, D. R. 2002. Harvest date influences fruit size and yield of 'York' and ‘Golden Delicious' apple trees. J. Tree Fruit Prod. 3: 63-79.

Byers, R. E., Carbaugh, D. H., Combs, L. D. and Smith, A. H. 2005. Ethylene inhibitors delay fruit drop, maturity, and increase fruit size of 'Arlet' apples. HortScience. 40: 2061-2065.

Dal Cin, V., Danesin, M., Botton, A., Boschetti, A., Dorigoni, A. and Ramina, A. 2008. Ethylene and preharvest drop: The effect of AVG and NAA on fruit abscission in apple (Malus domestica L. Borkh). Plant Growth Regul. 56: 317-325.

Ford, E. M. 1968. The response to Epsom salt sprays of mature apple trees of three varieties on two contrasting rootstocks. J. Hortic. Sci. 43: 505-517. 
Forshey, C. G. 1959. The effect of nitrogen status of magnesium deficient McIntosh apple trees on the response to Epsom salt sprays. Proc Am Soc Hortic Sci. 73: 40-45.

Forshey, C. G. 1963. Potassium-magnesium deficiency of McIntosh apple trees. Proc Am Soc Hortic Sci. 3: 12-20.

Greene, D. W., Krupa, J. and Autio, W. 2014. Factors influencing preharvest drop of apples. Proc. XIth IS Plant Bioregulators Fruit Prod, Acta Hortic. 1042: 231-236.

Greene, D. W. 2002. Preharvest drop control and maturity of 'Delicious' apples as affected by aminoethoxyvinylglycine (AVG ). J. Tree Fruit Prod. 3: 1-10.

Greene, D. W. 2005. Time of aminoethoxyvinylglycine application influences preharvest drop and fruit quality of 'McIntosh' apples. HortScience 40: 2056-2060.

Greene, D. W. 2006. An update on preharvest drop control of apples with aminoethoxyvinylglycine (ReTain). Proc. XIth IS Plant Bioregulators Fruit Prod, Acta Hortic. 727: 311-320.

Greene, D. W. 2010. The development and use of plant bioregulators in tree fruit production. Proc. XIth IS Plant Bioregulators Fruit Prod, Acta Hortic. 884: 31-40.

Greene, D. W. and Schupp, J. R. 2004. Effect of aminothoxyyinylglycine (AVG) on preharvest drop, fruit quality, and maturation of 'McIntosh' apples. II. Effect of timing and concentration relationships and spray volume. HortScience. 39: 1036-1041.

Hanson, E. J. 1991. Movement of boron out of tree fruit leaves. HortScience. 26: 271-273.

Harb, J., Gapper, N. E., Giovannoni, J. J. and Watkins, C. B. 2012. Molecular analysis of softening and ethylene synthesis and signaling pathways in a non-softening apple cultivar, 'Honeycrisp' and a rapidly softening cultivar, 'McIntosh'. Postharvest Biol. Technol. 64: 94-103. 
Hoying, S. A. and Robinson, T. L. 2010. Mechanics of drop control in the orchard: Use of NAA, Retain and Harvista. Cornell Univ. Dep. Hortic. 1-4.

Iglesias, I., Echeverria, G. and Soria, Y. 2008. Differences in fruit colour development, anthocyanin content, fruit quality and consumer acceptability of eight 'Gala' apple strains. Sci. Hortic. 119: 32-40. doi:10.1016/j.scienta.2008.07.004

Irish-Brown, A., Schwallier, P., Shane, B. and Tritten, B. 2011. Why does apple fruit drop prematurely? Michigan State Univ. Ext. [Online] Available: http://msue.anr.msu.edu/news/why_does_apple_fruit_drop_prematurely [2015 April 13].

Li, J. and Yuan, R. 2008. NAA and ethylene regulate expression of genes related to ethylene biosynthesis, perception, and cell wall degradation during fruit abscission and ripening in ‘Delicious’ apples. J. Plant Growth Regul. 27: 283-295.

Link, H. 2000. Significance of flower and fruit thinning on fruit quality. Plant Growth Regul. 31: 17-26.

Marini, R. P. 2004. Combinations of ethephon and accel for thinning 'Delicious' apple trees. J. Am. Soc. Hortic. Sci. 129: 175-181.

Marini, R. P., Byers, R. E. and Sowers, D. L. 1993. Repeated applications of NAA control preharvest drop of 'Delicious' apples. J. Hortic. Sci. 68: 247-253.

Miller, D.D. and Racsko, J. 2011. Rootstock effects on fruit drop and quality of 'Gala Galaxy' and 'Golden Delicious Reinders' apples. Proc. IXth IS on Orchard Systems, Acta Hortic. 903: $397-404$.

OMAFRA. 2014. Publication 360 guide to fruit production: 2014-2015. Queens Printer of Ontario. Toronto, Ontario, Canada.

Poapst, P. A., Ward, G. M. and Phillips, W. R. 1959. Maturation of McIntosh apples in relation to 
starch loss and abscission. Can. J. Plant Sci. 39: 257-263.

Reuther, W. 1942. Influence of boron application on preharvest drop of McIntosh apples. Proc Am Soc Hortic Sci. 40: 31-34.

Roberts, J. A., Elliott, K. A. and Gonzalez-Carranza, Z. H. 2002. Abscission, dehiscence, and other cell separation processes. Annu. Rev. Plant Biol. 53: 131-158.

Robinson, T., Hoying, S., Iungerman, K. and Kviklys, D. 2010. AVG combined with NAA control pre-harvest drop of 'McIntosh' apples better than either chemical alone. Proc. XIth IS Plant Bioregulators Fruit Prod, Acta Hortic. 884: 343-350.

Robinson, T. L., Watkins, C. B., Hoying, S. A., Nock, J. F. and Iungerman, K. I. 2006. Aminoethoxyvinylglycine and 1-methylcyclopropene effects on 'McIntosh' preharvest drop, fruit maturation and fruit quality after storage. Proc. XIth IS Plant Bioregulators Fruit Prod, Acta Hortic. 4: 473-480.

Rosenberger, D., Schupp, J., Watkins, C., Iungerman, K., Hoying, S., Straub, D. and Cheng, L. 2001. Honeycrisp: Promising profit maker or just another problem child? New York State Hortic. Soc. 9: 4-8.

Schupp, J. R. and Greene, D. W. 2004. Effect of aminoethoxyvinylglycine (AVG) on preharvest drop, fruit quality, and maturation of 'McIntosh' apples. I. Concentration and timing of dilute applications of AVG. HortScience. 39: 1030-1035.

Southwick, L. 1938. Pre-harvest drop of the McIntosh apple. Master's Thesis. Mass. State College, Amherst.

Southwick, L. 1943. Magnesium deficiency in Massachusetts apple orchards. Proc Am Soc Hortic Sci. 42: 85-94.

Ullah, S., Khan, A. S., Malik, A. U., Afzal, I., Shahid, M. and Razzaq, K. 2012. Foliar 
application of boron influences the leaf mineral status, vegetative and reproductive growth, yield and fruit quality of Kinnow' mandarin (Citrus reticulata Blanco.). J. Plant Nutr. 35: 2067-2079.

Unrath, C. R., Obermiller, J. D., Green, A. and McArtney, S. J. 2009. The effects of aminoethoxyvinylglycine and naphthaleneacetic acid treatments on abscission and firmness of 'Scarletspur Delicious' apples at normal and delayed harvests. HortTechnology. 19: 620625.

Vágó, I., Balla Kovács, A. and Nagy, P. T. 2007. Effects of boron, calcium and magnesium foliar fertilization on apple (Malus domestica) yields. Cereal Res. Commun. 35: 1261-1264.

Ward, D., Marini, R. and Byers, R. 2001. Relationships among day of year of drop, seed number, and weight of mature apple fruit. HortScience. 36: 45-48.

Wills, R., McGlasson, B., Graham, D. and Joyce, D. 2007. Postharvest: An introduction to the physiology and handling of fruit, vegetables and ornamentals. Pages 1-252. UNSW Press, 5 eds.

Wójcik, P., Cieslinski, G. and Mika, A. 1999. Apple yield and fruit quality as influenced by boron applications. J. Plant Nutr. 22: 1365-1377. doi:10.1080/01904169909365719

Wojcik, P. and Wojcik, M. 2006. Effect of boron fertilization on sweet cherry tree yield and fruit quality. J. Plant Nutr. 29: 1755-1766. doi:10.1080/01904160600897471

Wojcik, P., Wojcik, M. and Klamkowski, K. 2008. Response of apple trees to boron fertilization under conditions of low soil boron availability. Sci. Hortic. 116: 58-64. doi:10.1016/j.scienta.2007.10.032

Wooldridge, J. 2002. Effect of foliar- and soil-applied boron in deciduous fruit orchards 1: Apple and pear. South African J. Plant Soil. 19: 137-144. doi:10.1080/02571862.2002.10634453 
Yildiz, K., Ozturk, B. and Ozkan, Y. 2012. Effects of aminoethoxyvinylglycine (AVG) on preharvest fruit drop, fruit maturity, and quality of 'Red Chief' apple. Sci. Hortic. 144: 121124.

Yuan, R. and Carbaugh, D. H. 2007. Effects of NAA, AVG, and 1-MCP on ethylene biosynthesis, preharvest fruit drop, fruit maturity, and quality of 'Golden Supreme' and ‘Golden Delicious' apples. HortScience. 43: 1454-1460.

Yuan, R. and Li, J. 2008. Effect of sprayable 1-MCP, AVG, and NAA on ethylene biosynthesis, preharvest fruit drop, fruit maturity, and quality of 'Delicious' apples. HortScience. 43: $1454-1460$.

Yuan, R. C. and Greene, D. W. 2000. Benzyladenine as a chemical thinner for 'McIntosh' apples. I. Fruit thinning effects and associated relationships with photosynthesis, assimilate translocation, and nonstructural carbohydrates. J. Am. Soc. Hortic. Sci. 125: 169-176. 


\section{Figure Captions}

Fig. 1. Pedicel of apple fruit following separation from the tree. While monitoring fruit drop, fruit were categorized based on the appearance of the abscission zone, where A) a smooth abscission zone indicated physiological abscission, and B) a jagged and irregular break in the pedicel indicated mechanical damage caused by external force. (Photos by M. Arseneault.)

Fig. 2. Cumulative fruit drop, by abscission, of 'Honeycrisp' apple fruit in response to PBR and nutrient sprays A) during 2014 at the University of Guelph Simcoe Research Station and B) during 2015 at a commercial orchard in Windham Centre. A horizontal arrow indicates the commercial harvest window 24 Sept to 2 Oct 2014 and 25 Sept to 7 Oct 2015. Vertical bars represent the standard error of the mean. $\mathrm{N}=6$

Fig. 3. Cumulative fruit drop, by abscission and mechanical damage, of 'Honeycrisp' apple fruit on untreated controls A) during 2014 at the University of Guelph Simcoe Research Station and B) during 2015 at a commercial orchard in Windham Centre. A horizontal arrow indicates the commercial harvest window 24 Sept to 2 Oct 2014 and 25 Sept to 7 Oct 2015. Vertical bars represent the standard error of the mean. $\mathrm{N}=6$ 
Table 1. Effects of foliar nutrient sprays on 'Honeycrisp' tree leaf Mg and B concentration. Treatments were applied during 2014 and 2015 at the University of Guelph Simcoe Research Station, Simcoe, Ontario, Canada ${ }^{a}$

\begin{tabular}{|c|c|c|c|c|}
\hline \multirow[t]{2}{*}{ Nutrient treatment } & \multicolumn{2}{|l|}{2014} & \multicolumn{2}{|l|}{2015} \\
\hline & $\begin{array}{l}\mathrm{B}^{b} \\
\left(\mu \mathrm{g} \cdot \mathrm{g}^{-1} \text { dry weight }\right)\end{array}$ & $\begin{array}{l}\mathrm{Mg}^{c} \\
\text { (\% dry weight) }\end{array}$ & $\begin{array}{l}\text { B } \\
\left(\mu g \cdot g^{-1} \text { dry weight }\right)\end{array}$ & $\begin{array}{l}\mathrm{Mg} \\
\text { (\% dry weight) }\end{array}$ \\
\hline Untreated Control & $22 b$ & $0.22 b$ & $34 b$ & $0.19 b$ \\
\hline $200 \mathrm{mg} \cdot \mathrm{L}^{-1} \mathrm{~B}$ (Solubor $\left.{ }^{\circledR}\right)$ & $76 a$ & $0.24 b$ & $39 a$ & $0.19 b$ \\
\hline $2000 \mathrm{mg} \cdot \mathrm{L}^{-1} \mathrm{Mg}\left(\mathrm{MgSO}_{4}\right)$ & $25 b$ & $0.41 a$ & $35 a b$ & $0.27 a$ \\
\hline$P$ value & $<0.0001$ & $<0.0001$ & 0.0123 & 0.0015 \\
\hline
\end{tabular}

Note: Means within a column not sharing a lowercase letter differ significantly at $\mathrm{P}<0.05$ level by Tukey's test $(\alpha=0.05, \mathrm{~N}=6)$.

${ }^{a}$ In 2014, repeat sprays of B were applied 48, 61, and 78 days after full bloom and Mg applied 48, 61, 78, and 93 DAFB. In 2015, both B and $\mathrm{Mg}$ were applied 53 and 67 DAFB.

${ }^{b} \mathrm{~B}$ nutrient concentration sufficiency range for apples is 20-60 ppm (OMAFRA, 2014).

${ }^{c} \mathrm{Mg}$ nutrient concentration sufficiency range for apples is $0.25-0.40 \%$ (OMAFRA, 2014). 
Table 2. Effect of AVG, NAA, B and Mg sprays on marketable yield, fruit number, fruit weight, and crop load of 'Honeycrisp' apple trees. Treatments were applied during 2014 at the University of Guelph Simcoe Research Station, Simcoe, Ontario, Canada

\begin{tabular}{|c|c|c|c|c|c|}
\hline Treatment $^{a}$ & $\begin{array}{l}\text { Time of } \\
\text { application }\end{array}$ & $\begin{array}{l}\text { Marketable yield }{ }^{b} \\
\left(\mathrm{~kg} \cdot \text { tree }^{-1}\right)\end{array}$ & $\begin{array}{l}\text { Marketable fruit } \\
\text { per tree }^{b}(\mathrm{n})\end{array}$ & $\begin{array}{l}\text { Marketable fruit } \\
\text { weight }^{b}(\mathrm{~g})\end{array}$ & $\begin{array}{l}\text { Marketable crop load } \\
\left(\text { marketable fruit } \cdot \mathrm{cm}^{-2} \mathrm{TCSA}^{d}\right.\end{array}$ \\
\hline Untreated Control & $\mathrm{NA}^{e}$ & 13.1 & 62 & 230 & 4.0 \\
\hline $125 \mathrm{mg} \cdot \mathrm{L}^{-1} \mathrm{AVG}$ & $4 \mathrm{WBAH}^{c}$ & 14.3 & 65 & 231 & 4.0 \\
\hline $20 \mathrm{mg} \cdot \mathrm{L}^{-1} \mathrm{NAA}$ & $2 \mathrm{WBAH}$ & 14.3 & 64 & 230 & 4.3 \\
\hline $\begin{array}{l}125 \mathrm{mg} \cdot \mathrm{L}^{-1} \mathrm{AVG}+ \\
20 \mathrm{mg} \cdot \mathrm{L}^{-1} \mathrm{NAA}\end{array}$ & $2 \mathrm{WBAH}$ & 13.2 & 54 & 246 & 3.7 \\
\hline $200 \mathrm{mg} \cdot \mathrm{L}^{-1} \mathrm{~B}$ & $\begin{array}{l}3 \text { repeat sprays, } \\
2 \text { weeks apart }\end{array}$ & 12.5 & 55 & 234 & 3.2 \\
\hline $2000 \mathrm{mg} \cdot \mathrm{L}^{-1} \mathrm{Mg}$ & $\begin{array}{l}4 \text { repeat sprays, } \\
2 \text { weeks apart }\end{array}$ & 11.7 & 45 & 263 & 2.7 \\
\hline$P$ value & & 0.4953 & 0.4239 & 0.4804 & 0.3364 \\
\hline
\end{tabular}

${ }^{a}$ Naphthaleneacetic acid (NAA), aminoethoxyvinylglycine (AVG), boron (B), magnesium (Mg).

${ }^{b}$ Total fruit, excluding preharvest fruit drop.

${ }^{c}$ Weeks before anticipated harvest (WBAH).

${ }^{d}$ Trunk cross sectional area (TCSA).

${ }^{e}$ NA denotes not applicable. 
Table 3. Effect of AVG, NAA, B and Mg sprays on fruit firmness, starch index, soluble solids, titratable acidity, and the rate of ethylene evolution of 'Honeycrisp' apples. Treatments were applied during 2014 at the University of Guelph Simcoe Research Station, Simcoe, Ontario, Canada

\begin{tabular}{|c|c|c|c|c|c|c|}
\hline Treatment $^{a}$ & $\begin{array}{l}\text { Time of } \\
\text { application }\end{array}$ & $\begin{array}{l}\text { Fruit firmness } \\
(\mathrm{N})\end{array}$ & $\begin{array}{l}\text { Starch index } \\
(1-8: \text { high-low } \\
\text { starch })^{b}\end{array}$ & $\begin{array}{l}\text { Soluble solids } \\
\text { (\% BRIX) }\end{array}$ & $\begin{array}{l}\text { Titratable acidity } \\
\left(\mathrm{mg} \text { malic acid } \cdot 100 \mathrm{ml}^{-1}\right)\end{array}$ & $\begin{array}{l}\text { Rate of ethylene evolution } \\
\left.\text { (nl ethylene } \cdot \mathrm{g} \text { fruit }{ }^{-1} \cdot \mathrm{hr}^{-1}\right)\end{array}$ \\
\hline Untreated Control & $\mathrm{NA}^{d}$ & $60.1 a b$ & $7.8 a$ & $10.8 a b$ & 42.8 & $12.2 a$ \\
\hline $125 \mathrm{mg} \cdot \mathrm{L}^{-1} \mathrm{AVG}$ & $4 \mathrm{WBAH}^{c}$ & $63.4 a$ & $5.3 c$ & $10.5 b$ & 43.9 & $0.2 b$ \\
\hline $20 \mathrm{mg} \cdot \mathrm{L}^{-1} \mathrm{NAA}$ & $2 \mathrm{WBAH}$ & $59.2 b$ & $7.8 a b$ & $10.9 a b$ & 41.5 & $11.1 a$ \\
\hline $\begin{array}{l}125 \mathrm{mg} \cdot \mathrm{L}^{-1} \mathrm{AVG}+ \\
20 \mathrm{mg} \cdot \mathrm{L}^{-1} \mathrm{NAA}\end{array}$ & $2 \mathrm{WBAH}$ & $63.1 a b$ & $6.9 b$ & $11.0 a b$ & 45.0 & $\mathrm{ND}^{d} b$ \\
\hline $200 \mathrm{mg} \cdot \mathrm{L}^{-1} \mathrm{~B}$ & $\begin{array}{l}3 \text { repeat sprays, } \\
2 \text { weeks apart }\end{array}$ & $63.5 a$ & $7.9 a$ & $11.5 a$ & 44.8 & $11.8 a$ \\
\hline $2000 \mathrm{mg} \cdot \mathrm{L}^{-1} \mathrm{Mg}$ & $\begin{array}{l}4 \text { repeat sprays, } \\
2 \text { weeks apart }\end{array}$ & $61.9 a b$ & $7.5 a b$ & $11.4 a$ & 46.5 & $8.3 a$ \\
\hline$P$ value & & $<0.0001$ & $<0.0001$ & 0.0026 & 0.6278 & $<0.0001$ \\
\hline
\end{tabular}

Note: Means within a column not sharing a lowercase letter differ significantly at $\mathrm{P}<0.05$ level by Tukey's test $(\alpha=0.05, \mathrm{~N}=6)$.

${ }^{a}$ Naphthaleneacetic acid (NAA), aminoethoxyvinylglycine (AVG), boron (B), magnesium (Mg).

${ }^{b}$ Blanpied and Silsby (1992)

${ }^{c}$ Weeks before anticipated harvest (WBAH).

${ }^{d}$ NA and ND denotes not applicable and not detectible, respectively. 
Table 4. Effect of AVG, NAA, B and Mg sprays on international standard CIELAB colour coordinates: L* (lightness), C* (chroma), and $\mathrm{H}^{0}$ (hue angle) of 'Royal Gala' fruit skin blush and ground colour. Treatments were applied during 2014 at the University of Guelph Simcoe Research Station, Simcoe, Ontario, Canada ${ }^{a}$

\begin{tabular}{|c|c|c|c|c|c|c|c|}
\hline \multirow[t]{2}{*}{ Treatment $^{b}$} & \multirow{2}{*}{$\begin{array}{l}\text { Time of } \\
\text { application }\end{array}$} & \multicolumn{3}{|l|}{ Blush } & \multicolumn{3}{|l|}{ Ground } \\
\hline & & $\mathrm{L}^{*}$ & $\mathrm{C}^{*}$ & $\mathrm{H}^{0}$ & $\mathrm{~L}^{*}$ & $\mathrm{C}^{*}$ & $\mathrm{H}^{0}$ \\
\hline Untreated Control & $\mathrm{NA}^{d}$ & $42.0 b$ & $39.8 b$ & $28.7 b$ & 70.4 & $40.4 c$ & $104.9 b$ \\
\hline $125 \mathrm{mg} \cdot \mathrm{L}^{-1} \mathrm{AVG}$ & $4 \mathrm{WBAH}^{c}$ & $48.1 a$ & $34.3 a$ & $42.1 a$ & 70.8 & $44.2 a$ & $111.3 a$ \\
\hline $20 \mathrm{mg} \cdot \mathrm{L}^{-1} \mathrm{NAA}$ & $2 \mathrm{WBAH}$ & $43.1 b$ & $38.4 b$ & $31.9 b$ & 71.3 & $41.5 c$ & $106.8 a b$ \\
\hline $\begin{array}{l}125 \mathrm{mg} \cdot \mathrm{L}^{-1} \mathrm{AVG}+ \\
20 \mathrm{mg} \cdot \mathrm{L}^{-1} \mathrm{NAA}\end{array}$ & $2 \mathrm{WBAH}$ & $47.9 a$ & $34.2 a$ & $41.3 a$ & 71.4 & $43.7 a b$ & $110.8 a$ \\
\hline $200 \mathrm{mg} \cdot \mathrm{L}^{-1} \mathrm{~B}$ & $\begin{array}{l}3 \text { repeat sprays, } \\
2 \text { weeks apart }\end{array}$ & $41.4 b$ & $40.5 b$ & $28.8 b$ & 72.7 & $40.8 c$ & $102.6 b$ \\
\hline $2000 \mathrm{mg} \cdot \mathrm{L}^{-1} \mathrm{Mg}$ & $\begin{array}{l}4 \text { repeat sprays, } \\
2 \text { weeks apart }\end{array}$ & $42.1 b$ & $40.6 b$ & $29.4 b$ & 71.3 & $41.8 b c$ & $104.5 b$ \\
\hline$P$ value & & $<0.0001$ & $<0.0001$ & $<0.0001$ & 0.1541 & $<0.0001$ & $<0.0001$ \\
\hline
\end{tabular}

Note: Means within a column not sharing a lowercase letter differ significantly at $\mathrm{P}<0.05$ level by Tukey's test $(\alpha=0.05, \mathrm{~N}=6)$.

${ }^{a}$ Lightness $\left(\mathrm{L}^{*}\right)$ defined as the intensity of an area from black to white $(0-100)$, chroma $\left(\mathrm{C}^{*}\right)$ defined as the purity of a colour (low is washed out, high is vivid), and hue $\left(\mathrm{H}^{0}\right)$ defined as similarity to red (0), yellow (60), and green (120).

${ }^{b}$ Naphthaleneacetic acid (NAA), aminoethoxyvinylglycine (AVG), boron (B), magnesium (Mg).

${ }^{c}$ Weeks before anticipated harvest (WBAH).

${ }^{d}$ NA denotes not applicable. 
Table 5. Effect of AVG, NAA, B and Mg sprays marketable yield, fruit number, fruit weight, and crop load of 'Honeycrisp' apple trees. Treatments were applied during 2015 at a commercial orchard in Windham Centre, Ontario, Canada

\begin{tabular}{|c|c|c|c|c|c|c|}
\hline Treatment $^{a}$ & $\begin{array}{l}\text { Time of } \\
\text { application }\end{array}$ & $\begin{array}{l}\text { Total yield } \\
\left(\mathrm{kg} \cdot \operatorname{tree}^{-1}\right)\end{array}$ & $\begin{array}{l}\text { Marketable yield }{ }^{b} \\
\left(\mathrm{~kg} \cdot \text { tree }^{-1}\right)\end{array}$ & $\begin{array}{l}\text { Marketable fruit per } \\
\operatorname{tree}^{b}(\mathrm{n})\end{array}$ & $\begin{array}{l}\text { Marketable fruit } \\
\text { weight }^{b}(\mathrm{~g})\end{array}$ & $\begin{array}{l}\text { Marketable crop load } \\
\left(\text { fruit } \cdot \mathrm{cm}^{-2} \text { TCSA }\right)^{d}\end{array}$ \\
\hline Untreated Control & $\mathrm{NA}^{e}$ & 27.7 & $17.2 c d$ & $81 a b$ & 215 & $3.9 a b$ \\
\hline $125 \mathrm{mg} \cdot \mathrm{L}^{-1} \mathrm{AVG}$ & $4 \mathrm{WBAH}^{c}$ & 28.0 & $24.8 a b$ & $108 a b$ & 239 & $4.9 a b$ \\
\hline $20 \mathrm{mg} \cdot \mathrm{L}^{-1} \mathrm{NAA}$ & $2 \mathrm{WBAH}$ & 31.9 & $25.6 a$ & $124 a$ & 206 & $6.0 a$ \\
\hline $\begin{array}{l}125 \mathrm{mg} \cdot \mathrm{L}^{-1} \mathrm{AVG}+ \\
20 \mathrm{mg} \cdot \mathrm{L}^{-1} \mathrm{NAA}\end{array}$ & $2 \mathrm{WBAH}$ & 26.7 & $23.7 a b c$ & $104 a b$ & 229 & $5.1 a b$ \\
\hline $200 \mathrm{mg} \cdot \mathrm{L}^{-1} \mathrm{~B}$ & $\begin{array}{l}2 \text { repeat sprays, } \\
2 \text { weeks apart }\end{array}$ & 28.1 & $14.6 d$ & $73 b$ & 204 & $3.6 b$ \\
\hline $2000 \mathrm{mg} \cdot \mathrm{L}^{-1} \mathrm{Mg}$ & $\begin{array}{l}2 \text { repeat sprays, } \\
2 \text { weeks apart }\end{array}$ & 26.0 & $18.1 b c d$ & $82 a b$ & 225 & $3.9 a b$ \\
\hline$P$ value & & 0.4582 & 0.0003 & 0.0134 & 0.2786 & 0.0190 \\
\hline
\end{tabular}

Note: Means within a column not sharing a lowercase letter differ significantly at $\mathrm{P}<0.05$ level by Tukey's test $(\alpha=0.05, \mathrm{~N}=6)$.

${ }^{a}$ Naphthaleneacetic acid (NAA), aminoethoxyvinylglycine (AVG), boron (B), magnesium (Mg).

${ }^{b}$ Total fruit, excluding preharvest fruit drop.

${ }^{c}$ Weeks before anticipated harvest (WBAH).

${ }^{d}$ Trunk cross sectional area (TCSA).

${ }^{e}$ NA denotes not applicable. 
Table 6. Effect of AVG, NAA, B and Mg sprays on fruit firmness, starch index, soluble solids, titratable acidity, and the rate of ethylene evolution of 'Honeycrisp' apples. Treatments were applied during 2015 at a commercial orchard in Windham Centre, Ontario, Canada

\begin{tabular}{|c|c|c|c|c|c|c|}
\hline Treatment $^{a}$ & $\begin{array}{l}\text { Time of } \\
\text { application }\end{array}$ & $\begin{array}{l}\text { Fruit } \\
\text { firmness }(\mathrm{N})\end{array}$ & $\begin{array}{l}\text { Starch index } \\
(1-8: \text { high-low starch })^{b}\end{array}$ & $\begin{array}{l}\text { Soluble solids } \\
\text { (\% BRIX) }\end{array}$ & $\begin{array}{l}\text { Titratable acidity } \\
\left(\mathrm{mg} \text { malic acid } \cdot 100 \mathrm{ml}^{-1}\right)\end{array}$ & $\begin{array}{l}\text { Rate of ethylene } \\
\text { evolution (nl } \\
\left.\text { ethylene } \cdot \text { fruit }^{-1} \cdot \mathrm{hr}^{-1}\right)\end{array}$ \\
\hline Untreated Control & $\mathrm{NA}^{e}$ & 61.6 & $2.8(7.7)^{d} a$ & 11.1 & $35.8 a b$ & $14.3 a b$ \\
\hline $20 \mathrm{mg} \cdot \mathrm{L}^{-1} \mathrm{NAA}$ & $2 \mathrm{WBAH}$ & 61.8 & $2.8(7.6) a$ & 11.0 & $34.3 b$ & $19.2 a$ \\
\hline $\begin{array}{l}125 \mathrm{mg} \cdot \mathrm{L}^{-1} \mathrm{AVG}+ \\
20 \mathrm{mg} \cdot \mathrm{L}^{-1} \mathrm{NAA}\end{array}$ & $2 \mathrm{WBAH}$ & 62.2 & $2.4(6.1) b c$ & 10.6 & $39.7 a b$ & $\mathrm{ND}^{e} c$ \\
\hline $2000 \mathrm{mg} \cdot \mathrm{L}^{-1} \mathrm{Mg}$ & $\begin{array}{l}2 \text { repeat sprays, } \\
2 \text { weeks apart }\end{array}$ & 61.9 & $2.7(7.5) a b$ & 11.0 & $37.3 a b$ & $11.1 b$ \\
\hline$P$ value & & 0.1585 & $<0.0001$ & 0.4590 & 0.0144 & $<0.0001$ \\
\hline
\end{tabular}

Note: Means within a column not sharing a lowercase letter differ significantly at $\mathrm{P}<0.05$ level by Tukey's test $(\alpha=0.05, \mathrm{~N}=6)$.

${ }^{a}$ Naphthaleneacetic acid (NAA), aminoethoxyvinylglycine (AVG), boron (B), magnesium (Mg).

${ }^{b}$ Blanpied and Silsby (1992)

${ }^{c}$ Weeks before anticipated harvest (WBAH).

${ }^{d}$ Data were square root transformed. The means in brackets are the untransformed values.

${ }^{e} \mathrm{NA}$ and ND denote not applicable and not detectible, respectively. 
Table 7. Effect of AVG, NAA, B and Mg sprays on international standard CIELAB colour coordinates: $\mathrm{L}^{*}$ (lightness), $\mathrm{C}^{*}$ (chroma), and $\mathrm{H}^{0}$ (hue angle) of 'Honeycrisp' fruit skin blush and ground colour. Treatments were applied during 2015 at a commercial orchard in Windham Centre,

\begin{tabular}{|c|c|c|c|c|c|c|c|}
\hline \multirow[t]{2}{*}{ Treatment $^{b}$} & \multirow{2}{*}{$\begin{array}{l}\text { Time of } \\
\text { application }\end{array}$} & \multicolumn{3}{|l|}{ Blush } & \multicolumn{3}{|l|}{ Ground } \\
\hline & & $\mathrm{L}^{*}$ & $\mathrm{C}^{*}$ & $\mathrm{H}^{0}$ & $\mathrm{~L}^{*}$ & $\mathrm{C}^{*}$ & $\mathrm{H}^{0}$ \\
\hline Untreated Control & $\mathrm{NA}^{e}$ & $45.8 b$ & $37.9 a b$ & $34.5 b$ & $72.8 a$ & $40.3 a b$ & $4.7(108.5)^{d} a b$ \\
\hline $125 \mathrm{mg} \cdot \mathrm{L}^{-1} \mathrm{AVG}$ & $4 \mathrm{WBAH}^{c}$ & $52.9 a$ & $34.3 b c$ & $51.6 a$ & $70.6 b$ & $41.9 a$ & $4.7(110.3) a$ \\
\hline $20 \mathrm{mg} \cdot \mathrm{L}^{-1} \mathrm{NAA}$ & $2 \mathrm{WBAH}$ & $45.7 b$ & $37.6 a b$ & $35.4 b$ & $72.7 a b$ & $40.3 a b$ & $4.7(107.4) a b$ \\
\hline $\begin{array}{l}125 \mathrm{mg} \cdot \mathrm{L}^{-1} \mathrm{AVG}+ \\
20 \mathrm{mg} \cdot \mathrm{L}^{-1} \mathrm{NAA}\end{array}$ & $2 \mathrm{WBAH}$ & $53.7 a$ & $33.4 c$ & $53.4 a$ & $71.0 a b$ & $42.4 a$ & $4.7(110.3) a$ \\
\hline $200 \mathrm{mg} \cdot \mathrm{L}^{-1} \mathrm{~B}$ & $\begin{array}{l}2 \text { repeat sprays, } \\
2 \text { weeks apart }\end{array}$ & $45.7 b$ & $38.2 a$ & $33.4 b$ & $72.1 a b$ & $39.2 b$ & $4.7(105.8) a b$ \\
\hline $2000 \mathrm{mg} \cdot \mathrm{L}^{-1} \mathrm{Mg}$ & $\begin{array}{l}2 \text { repeat sprays, } \\
2 \text { weeks apart }\end{array}$ & $45.6 b$ & $37.9 a b$ & $35.3 b$ & $70.5 b$ & $39.0 b$ & $4.6(103.8) b$ \\
\hline $\mathrm{P}$ value & & 0.0001 & 0.0006 & 0.0002 & 0.0061 & 0.0018 & 0.0061 \\
\hline
\end{tabular}

Note: Means within a column not sharing a lowercase letter differ significantly at $\mathrm{P}<0.05$ level by Tukey's test $(\alpha=0.05, \mathrm{~N}=6)$.

${ }^{a}$ Lightness $\left(\mathrm{L}^{*}\right)$ defined as the intensity of an area from black to white $(0-100)$, chroma $\left(\mathrm{C}^{*}\right)$ defined as the purity of a colour (low is washed out, high is vivid), and hue $\left(\mathrm{H}^{0}\right)$ defined as similarity to red (0), yellow (60), and green (120).

${ }^{b}$ Naphthaleneacetic acid (NAA), aminoethoxyvinylglycine (AVG), boron (B), magnesium (Mg).

${ }^{c}$ Weeks before anticipated harvest (WBAH).

${ }^{d}$ Data were $\log$ transformed. The means in brackets are the untransformed values.

${ }^{e}$ NA denotes not applicable. 

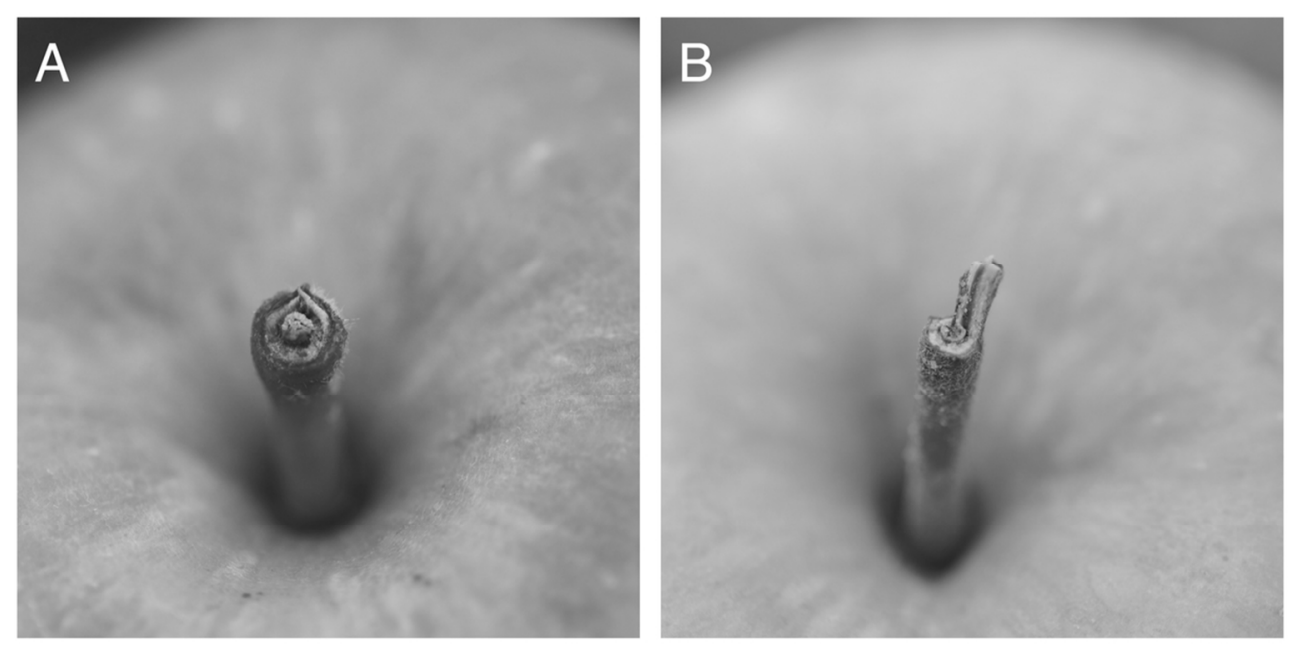

$104 \times 52 \mathrm{~mm}(300 \times 300 \mathrm{DPI})$ 

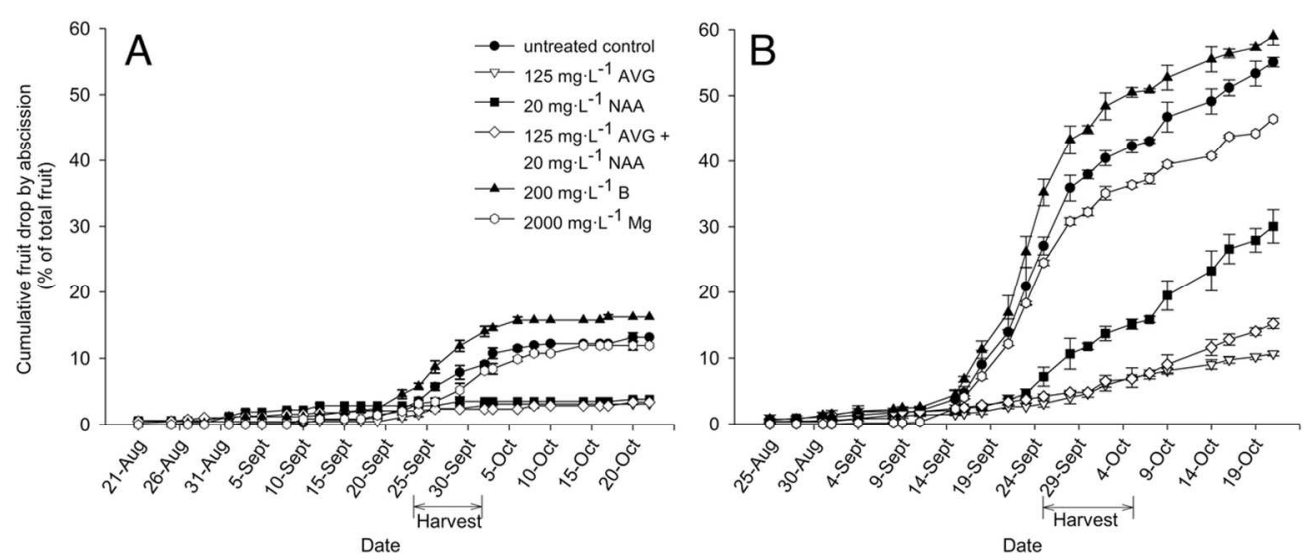

$55 \times 23 \mathrm{~mm}(600 \times 600 \mathrm{DPI})$ 

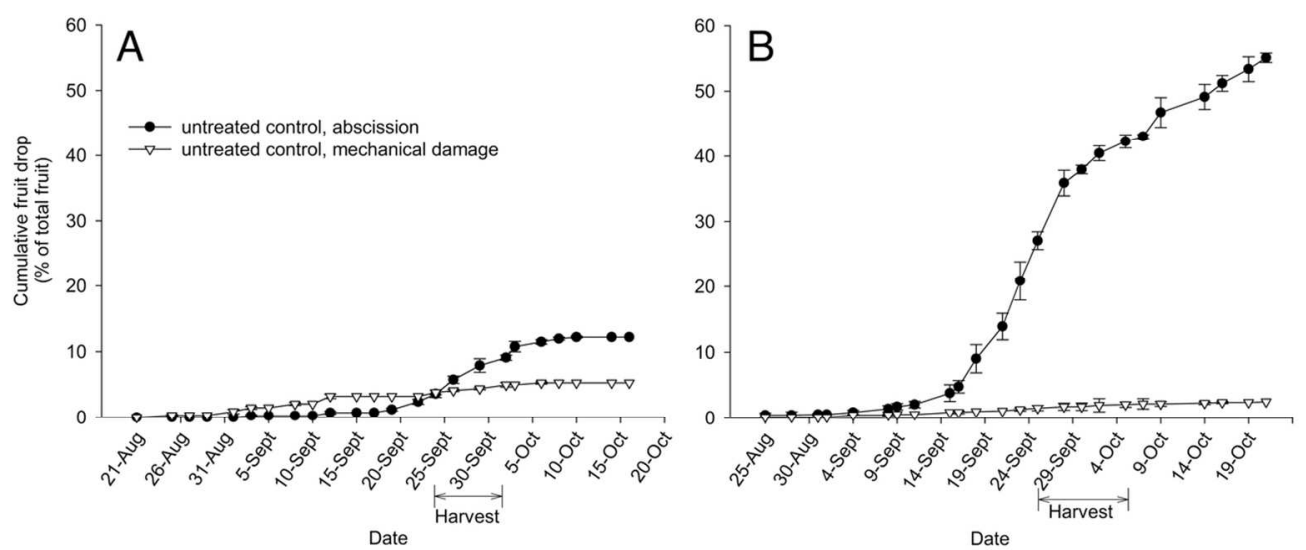

$55 \times 23 \mathrm{~mm}(600 \times 600 \mathrm{DPI})$ 